\title{
Promoting the Online Service Product of PT. Mandiri Sekuritas Using a Promotional Video
}

\author{
Yaphilia, D. \\ English Department, Faculty of Letters, Petra Christian University, \\ Siwalankerto 121-131, Surabaya 60236, East Java, INDONESIA \\ E-mails: devina.yaphilia26@gmail.com
}

\begin{abstract}
This Business Communication Final Project (BCFP) is made for PT. Mandiri Sekuritas, one of the biggest securities company in Indonesia. The background of the study is the fact the most of the Online Service product's members are passive, or also called as "sleeping clients". This problem can affect the AR (Assets Ratio) of the company because they are passive traders. Thus, PT. Mandiri Sekuritas needs to make a promotional video. The video will be uploaded in big websites such as YouTube and e-mail. The video is divided into two parts: The first part is dedicated to the people who are new to stocks and the second part is dedicated to the existing members of Mandiri Sekuritas but rarely do anything with their account. In the video, I highlight two things: the importance of joining stock investment and the importance of being active in stocks trading. By making this video, I want to tell all people especially those who are at young age that investment is important for their future and Mandiri can answer their needs very well. Also, those "sleeping clients" can realize that being active will bring them many benefits and that the company cares for them.
\end{abstract}

Keywords:

A promotional video, promotional tool, securities company,

Online Service product

\section{INTRODUCTION}

Mandiri Sekuritas is the result of a merger of several securities in Bank Mandiri, namely Bumi Daya Sekuritas, Exim Securities, and Merincorp Securities Indonesia which has been effective since August 25, 2000. Mandiri Sekuritas has the biggest number of customers compared to other securities companies. Online Service is one of Mandiri Sekuritas products which enables the clients to do stocks trading by themselves. Unfortunately, many of Online Service members are passive in trading. Those who are considered "sleeping clients" tend to just open an account in Mandiri Sekuritas' Online Service and do nothing with it. There are several possible reasons why they are not active in doing the trading. First of all, they make an account in Mandiri Sekuritas because they only have to spend two million rupiahs for the initial deposit. Secondly, since the initial deposit of the Online Product is cheap, people tend to 'underestimate' this service. This problem is important to be solved because it may decrease the AR (Assets Ratio) of the company significantly which will be resulting in a lower company's earning if no action taken. Due to the "sleeping clients" problem that Mandiri Sekuritas has until now, I made a promotional video to overcome this problem. It contains the explanation of why doing stock investment is important and why being an active trader is also important.

There are some benefits that PT. Mandiri Sekuritas will get by having this company profile video. First of all, PT. Mandiri Sekuritas will get a promotional tool that can promote their Online Service product effectively to its customers. By seeing the video, the clients can know why they have to be active, why Mandiri Sekuritas is the best choice, what benefits they will get from being active, and many more. Therefore, it can help to increase PT. Mandiri Sekuritas' brand awareness and customers can have better understanding of this company, specifically the Online Service the company provides. Second of all, the video will increase the company's AR (Assets Ratio). Since the video will be visually appealing and designed professionally, the existing clients will get motivated to do transactions. If more existing clients do transactions, the assets of the company will automatically increase because of the velocity of money inside it. The existing clients can act as a "money booster" to the company. Not only will the existing clients increase the assets, but new 
clients can also do so. The video will not only be sent to the existing clients, but it will also be displayed on the official website of Mandiri Sekuritas. This can be a good chance because they can see the promotional video freely and it can be a good start to encourage all people who watch the video to open their own account in Mandiri Sekuritas. Therefore, this video will be very useful to boost the assets that Mandiri Sekuritas has.

\section{PRINCIPLES FOR DESIGNING NEW PRODUCTS}

To make and finish this project completely, I use some information from online sources to understand the definition, purposes, and features used in making a promotional video.

Before going further, I will first define the word "promotion". "Promotion", according to Belch, George. E. and Belch, Michael. A. (2003), is defined as "The coordination of all sellerinitiated efforts to set up channels of information and persuasion to sell goods and services or promote an idea" (p. 792). Whereas according to en.oxforddictionaries.com, promotion means "The publicizing of a product, organization, or venture so as to increase sales or public awareness." The definition of "tool" according to the dictionary.com is "anything used as a means of accomplishing a task or purpose". From the definitions I have mentioned above, I can conclude that the meaning of promotional tools is the planned act of marketing a product or service to persuade customers to buy in order to increase the sales.

\section{Definition of Promotional Video}

In addition, dictionary.cambridge.org defines the word 'Promotional' as "Intended to advertise something" and According to en.oxforddictionaries.com, the word 'video' is described as "The recording, reproducing, or broadcasting of moving visual images." From these definitions, I can conclude that Promotional Video is an act of publicizing information which is created and shown through moving visual images to reach a certain target market. Video is just one of the promotional tools that are used by many people nowadays. Many companies and businesses are no longer promoting their products or services through printed forms. Now, many companies and business are promoting their products or services through a video because it has lower cost and wider viewer range. Therefore, I chose to make a promotional video to promote the Online Service product of PT. Mandiri Sekuritas Surabaya.

\section{The Significance of Video Form In Making This Project}

Solving the problem using a promotional video is a good choice to get a good result. Based on Walter\&Gioglio (2014), there are some points that prove why making a visual content is worth to be considered:

1. Human brain is more likely to absorb visual information 60.000 times faster than plain text information

2. $94 \%$ people who view a video is attracted by its compelling content and images

3. Visual content is undoubtedly increasing people's engagement

4. $62 \%$ of respondents to a survey conducted by Custom Content Council stated they use video as their marketing tools

5. Video posting draw customers' attention three times more than just plain text post

6. It is estimated that $85 \%$ video viewers tend to buy the product after watching the video of it

\section{Branding}

When the promotional video disclose the PT. Mandiri Sekuritas' business idea, it is basically telling the brand's story. Based on Matthew Healey (2008), he stated three different meanings inspired by Patrick Barwise's book titled The Economist's 2004 collection of essays Brands and Branding on what a brand can be:

- An identifying mark (refers to the branded thing itself) on products or services, such as Zara or Shangri-La Hotel

- A logo (can be a name or symbol) that identifies certain products or services, such as M (McDonald) or JNE

- A customer's assumption on certain products or services by its tagline like BMW's, "Designed for Driving Pleasure" (often called brand equity) 
The next level that should be done will be branding. According to this book, branding is forming strong bonds between the brand and the customers so that it is recognized and identified well as what the brand says it will be. Here, branding is one out of many things that can ensure the success story of a product or service because it can:

- Build up a good image

- Push customers' loyalty

- Guarantee quality

- Creates perception in customer's mind toward product's worthiness

- Allow the buyer to feel the sense of belonging toward the product because of its values

A good branding will make the customers feel better after buying a product or service even though there are other competitors in the marketplace. PT. Mandiri Sekuritas has had a good image because of its good and stable performances, services, facilities, and quality. Even so, branding is something that needs to be done over and over again to give a stronger sense of this company's image. Even though Mandiri Sekuritas is a well-known securities company, not all people are aware of what Mandiri Sekuritas really is. Most of them are familiar with Mandiri Sekuritas because it has 'Mandiri' term in it, and not knowing what it really stands for. Therefore, making a promotional video is one way to spread the image to the people out there.

\section{Marketing}

After having done with the branding, the next important step is marketing. The purposes are to keep the existing customers and to attract new people. In fact, marketing is not just selling things to make people buy it, but it is more on building relationships, especially the long-standing ones between a company and its customers.

YouTube Marketing

Here, I decided to use two ways to market the promotional video. The first one is through YouTube, and the other one is through E-mail Marketing. Most all people know what YouTube is. Since its emergence in 2005, YouTube has made the new trend of promoting something through video content. Interestingly, young people nowadays tend to make their buying decision based on a video. According to Walter\&Gioglio (2014), young consumers with an age range between 18-34year-olds are twice likely to decide their preferred product or service through the video they have seen, $38 \%$ of them tend to visit the physical store directly after watching a video, and $34 \%$ of them tend to buy the product being advertised in the online video ad. Moreover, YouTube offers several benefits to its users who want to market their product or service's video. Firstly, the company can determine the country in which the video should be more appeal based on its target market, even though everybody can still see it. Secondly, posting a video on YouTube may create the image of a 'friendly company' since the information can be reached by all people around the world. Thirdly, marketing a product or service on YouTube means the company makes its product or service visible on Google too. Last but not least, YouTube can help a company to do a research in comparing one product to another. In addition, this promotional video will be uploaded to YouTube which can be seen by as many people and increases PT. Mandiri Sekuritas' brand awareness and recognition on people's mind.

\section{E-mail Marketing}

In addition, besides YouTube, e-mail marketing is also used by many companies to promote their products or service. Simms Jenkins (2009) stated, "Email is a powerful marketing tool" (p.1). Therefore, Simms Jenkins mentioned several reasons on why email marketing is a great tool as follows:

1. It helps a company to connect with its customers in a more personal way

2. It is cost-effective

3. It has clear target market

4. It is immediate and actionable

5. It is seen as a professional tool 
Even though some companies are now focusing on making videos, but those business people know better how important and effective email marketing is. Email can be considered as one of the branding tools since it represents one's reputation. People's perspective can be shaped only by seeing the email coming from a particular company. Effective email messaging can lead to a better result at the end, such as people forwarding it to others, people take an action after seeing it, and many more. Regardless of the content of the message being delivered in the email, the sender of the email (or the company) will also be the center of the attention when people first see it. As stated by Mullen\&Daniels (2009), it says that a well-known company is more likely to get its email opened by people who receive it compare to the email from the unknown or small company. Since PT. Mandiri Sekuritas is well-known, the chance is higher for people to be triggered to open it to know what is inside.

\section{Criteria for a Good Product Video}

Therefore, creating a good video to promote a product or service is important. By creating a promotion video like this, the purpose of making the video can be fulfilled and transferred well to the targeted clients. I use sitepoint.com as my guidance in making good product documentation. There are six criteria that can create a good product documentation either it is in a written or video form.

The first criteria is it should explain what the product is and what function does the product serves. This is important because if clients do not get what a company is trying to sell, they will not bother to buy or use the product or service offered by the company.

The second criteria is it should explain the product or service's uniqueness. By having this, the clients can know why they have to use the products or services of a certain company.

The third criteria is it should tell the viewers how to get started with the product or service. We cannot simply tell the product or services we have to the viewers, but we also need to show them how to start the experience of using the products or services.

The fourth criteria is it should tell the viewers how to use it. After telling the viewers how to start experiencing it, telling how to use the product or service is the next step that needs to be done.

The fifth criteria is it should tell the best way to use the product or service. In other words, this criteria allows the viewers to know the best practice to experience the product or service offered by the company.

The last criteria is it should give examples of how the product or service works. By having this in the documentation, or in this case in a video, the viewers can understand what benefits they will have and know the importance of using the product or service.

Based on the same source, there are also 4 things that a good documentation should have. A good documentation should be complete, concise, organized, and up-to-date. This way, the message that the company is trying to deliver will be received well by the viewers or the client-tobe.

Therefore, the information I have written below can be my guide to make a video to promote the Online Service product of Mandiri Sekuritas. These criteria help me to make this project. This project is made in a form of video to catch more potential clients by the content of the video. A good content can easily draw the existing and client-to-be's attention to use this product actively, the Online Service product.

\section{PRODUCTS AND RATIONALE}

Here, I make a promotional video for PT. Mandiri Sekuritas which promotes one of its products, the Online Service. The main purpose of this video is to encourage the existing Online Service clients of Mandiri Sekuritas to be active in trading and doing transactions. Not only this video can encourage the existing clients, but also it can act as a mean to attract new potential clients. The concept of the video is informative-animation. The main target market for this video is the existing Online Service clients of Mandiri Sekuritas. The other target market of this video is all people who watch the video, especially the existing Online Service clients of PT. Mandiri Sekuritas Surabaya with age between 20-40 years old. The following are the purposes of the video:

1. For Prospects (college students and young workers aged 40 and below): 
a. To attract young people to invest their money in stocks

b. To encourage them to become a member of Mandiri Sekuritas

2. For "Sleeping Clients" (college students and young workers aged 40 and below):

a. To encourage the clients who do not know and have never done any transaction to begin doing a transaction

b. To encourage the clients who are afraid to do a transaction because of their failures in the past to do a transaction again

Content of the Video for the Viewers: (in Bahasa)

A. Untuk Prospek:

Judul: "Mengapa Harus Berinvestasi Saham di Mandiri Sekuritas?"

1. Pentingnya Berinvestasi dalam Saham

2. Pentingnya Bergabung dengan Mandiri Sekuritas

B. Untuk "Sleeping Clients":

Judul: "Mengapa Harus Menjadi Anggota yang Aktif? Bisakah Sukses?"

1. Contoh Layanan yang Tersedia di Mandiri Sekuritas

2. Contoh Anggota Mandiri Sekuritas yang Aktif \& Sukses

Video Type: Animation

Dominant Colors of the Character: Dark Blue dan Golden Yellow

There are reasons why I decided to make the video as what I have written above. First of all, the reason why I put the "for prospects" point at the first part is to attract people's attention to stay on the video and find out what the video is about. If I put the second point in the first part, the "for sleeping clients" point, people who have no idea about stocks and Mandiri Sekuritas will tend to skip the video. Those people will skip the entire video because they might think that this video is not made for them. In other words, by putting out the "for prospects" point first, people will think that this video is made for people in general and after seeing the video for few seconds, they will not mind to watch it entirely.

Second of all, I use Bahasa as the main language of this video. The reason why I use Bahasa as the main language is that PT. Mandiri Sekuritas is a local company. Almost all of its clients are Indonesian. Also, there are still a lot of Indonesian people who are not registered at any securities company yet. Based on the fact from any source in the internet, Indonesia has over 260 million citizens. Regardless of the amount of population Indonesia has, there are only 600.000 people who are registered as a member of a securities company. The chance to get more clients within Indonesia is very big. Indonesian population is also dominated by young people. Therefore, by using Bahasa as the main language for the video, all people can understand the content and message of the video better. Even though the video is made in Bahasa, foreigners can also enjoy the video as well since I provide English subtitle.

Third of all, I decided to make the video in an animation form. The reason why I decided to make it into an animation video is that first, animation has the ability to express complicated ideas easily and quickly (Hribernik, 2017). The simplest example of this is, in live video, I will not be able to ask Warren Buffet, Ray Dalio, and Lo Kheng Hong to be the actors of my video. On the other hand, in animation video, I am able to create whatever visuals I want to put in the video. I can make it in $2 \mathrm{D}, 3 \mathrm{D}$, or whatever style I want to create depending on my concept whether the video wants to create a friendly, creative, warm, or professional look. It can be far better than live action at sending people the message of the video. Second, animation has the ability to create a good outcome with fewer types of equipments and preparation with a good outcome. Third, animation has the ability to make changes at the video at any time (Cook, 2016). Changing some parts in animation video is way easier since it will be done by the video maker at no time.

Lastly, I decided to give the man character, the representative of PT. Mandiri Sekuritas, two dominant colors which are dark blue and golden yellow. Dark blue and golden yellow are the color of PT. Mandiri Sekuritas logo. I used these colors so that both logo and the promotional video has the same intention to symbolize all the meanings that PT. Mandiri Sekuritas logo has. According to bankmandiri.co.id, the dark blue color symbolizes command, respect, reliable, trust, integrity, and professionalism. Meanwhile, gold yellow symbolizes greatness, glory, prosperity, 
and wealth. This color is also believed to make people think that they have better future. In addition, color consistency is very important for a brand. According to fssi-ca.com, brands' consistency and identifiable can be every company's secret weapon, like color, for instance. Color consistency is crucial to avoid confusion in consumers' mind. Using persistent brand color in any of one's company media, such as its official website, marketing tools, etc, will make the brand more recognized better in the future because people are seeing the same thing every time they are searching for that company.

\section{CONCLUSION}

For my Business Communication Final Project, I decided to make a promotional video for one of Mandiri Sekuritas products, Online Service, for PT. Mandiri Sekuritas. I decided to address the "sleeping clients" problem as my Business Communication Final Project Report. I chose that problem because from what I have seen so far, this problem needed the most attention from the company and was the most crucial than other problems I found there. Then, a promotional video is the solution to overcome this problem which will contain the reason why people should invest their money in stock and why the members should be active in doing stock trading.

There are two purposes of this promotional video. The first is to give understanding to all Mandiri Sekuritas Online Service members about the importance of being active in stocks trading and doing transactions. The second purpose is to attract new clients to join the membership of Online Service of Mandiri Sekuritas. By watching this promotional video, the existing Mandiri Sekuritas Online Service members can be convinced of why they have to be active and all people who have not joined the membership of Mandiri Sekuritas can realize the importance of doing stocks investment for their future. Hence, I can say that this promotional video is very useful and helpful for both target markets.

This video is made of two parts, which are for prospects and "sleeping clients". The first part is made for people in general, especially for youngsters. At this part, the video explains the importance of stocks investment and why people should join Mandiri Sekuritas. The second part is made for the existing members of the Online Service of Mandiri Sekuritas. At this part, the video explains the services and facilities available in Mandiri Sekuritas (in case they do not know) and living proof of Mandiri Sekuritas members who have succeeded through stocks investment in a form of testimonial video. Then, the video is closed by PT. Mandiri Sekuritas' logo. Aside from those two main parts, the video contains some features, such as music background, Indonesian narration, and English subtitle which are made to make the audience have better understanding on the video.

Last but not least, through this promotional video, I hope it has a really good outcome so that PT. Mandiri Sekuritas can solve their "sleeping clients" problem. It also serves as the solution for various problems in the company. This video can be used as an effective explainer tool for the two target markets to tell people what they should do. PT. Mandiri Sekuritas can also show this video in any event they will hold in the future. As a result, not only will people get all the advantages from the video by doing it, but also it can increase the AR (Assets Ratio) of the company. Therefore, this video can give a good impact on the clients' satisfaction since they know that they are taken care of by the company.

For those EBC students who are on their internship period, it will be much better if they can start thinking about the problem they are going to solve on their project later on and find time to talk about this important project to their supervisor whether they are interested in doing this project or not. It will be better if the explanation is done in a form of semi-formal presentation so that they can explain the problem, research, and so on formally and make their leaders convinced by their explanations. By mentioning the problem and the research they have observed during their internship period, it can make the company more aware that there are actually some problems hanging on their company that an outsider can point out and speak it out bravely. In addition, the students also need to consider some things if they decide to choose a video as their project such as the time and price of it. The students also need to make sure that the company is willing to pay the amount of money they proposed for the project; otherwise, they will pay for the project using their own money. 


\section{REFERENCES}

Promotion [Def. 2] (n.d.) In Oxford Dictionaries Online, Retrieved from https://en.oxforddictionaries.com/definition/promotion

Video [Def.1] (n.d.) In Oxford Dictionaries Online, Retrieved from https://en.oxforddictionaries.com/definition/video

Hainla, L. (2017, November 21). 8 Powerful Reasons You Need to Use Video Marketing. Retrieved from https://www.dreamgrow.com/8-reasons-why-your-business-

should-use-video-marketing/

Promotional [Def.1] (n.d) In Cambridge Dictionary Online, Retrieved from http://dictionary.cambridge.org/dictionary/english/promotional

Arti Dan Filosofi Logo Baru Bank Mandiri [Def] (n.d) In Bank Mandiri Official Website, Retrieved from http://www.bankmandiri.co.id/promo/mandiribaru.aspx

Gerchev, I. (2014, April 25). Is Your Product's Documentation Good Enough? Retrieved from https://www.sitepoint.com/products-documentation-good-enough/

Hribernik, T. (2017, April 13). Animation VS Live Action. Which Style Is Better? Retrieved from http://videosauce.net/animation-or-live-action-best-style/

Cook, E. (2016, December 15). Animation VS Live Action:Which Makes The Best Corporate Video? Retrieved from https://www.skeletonproductions.com/insights/animation-vs-live-action

Achieving Brand Consistency Through Color Management - And Why It's Important to Your Business. (2017, February 23). Retrieved from www.fssi-ca.com/achieving-brandconsistency-through-color-management-and-why-its-important-to-your-business/ Healey, M. (2008). What Is Branding? Singapore: Page One Publishing Pte Ltd Jarboe, G. (2009). YouTube and Video Marketing. Canada:Wiley Publishing, Inc,. Indianapolis,Indiana

Jenkins, S. (2009). The Truth About Email Marketing. United States of America: Pearson Education, Inc.

Mullen, J., \& Daniels, D. ( 2009). Email Marketing. C Canada:Wiley Publishing, Inc,. Indianapolis,Indiana

Walter, E., \& Gioglio, Jessica. (2014). The Power of Visual Storytelling. United States of America.

Belch, George. E., \& Belch, Michael. A. (2003). Advertising and Promotion ( $6^{\text {th }}$ ed.). Retrieved from http://lib.dtc.ac.th/ebook/BusinessAdministration/5183.pdf. United States: The McGraw-Hill Companies. 